cured more bad cases of inebriety than any other remedy, but my ultra scientific friend scared me off the track, by telling me I was "dogmatic" (whatever that may mean). They tell me that the cases I report as cured are only (I)parently well. I ask them now, how is it with the men who have been scientifically cured; are they well or only apparently well? There are relapses in both cases; does the relapse prove that no one has been cured? If such a theory is true,there is no way to tell when a case has been cured. If drunkenness is a disease and the inebriate is like the patient with typhoid fever, entirely irresponsible for his acts, it is high time that it should be known. There is no earthly use for courts of justice fooling away their time with business that belongs exclusively to the medical profession. There has been a great wrong done to drunkards and doctors too. The drunkard has been punished and the doctor has lost his legitimate fees. Lawyers are responsible for this. They knew all the time that the drunkard was only sick! And instead of sending for the doctor they send for a policeman, have the poor drunkard imprisoned and get a fee for having him released, when the proper thing was to send for a doctor who obtains a fee for his call and prescription and sends the man where he belongs (to a hospital) where he can be cured and the bospital doctor gets his proper fee.

I think the editor is striking out in the proper direction. If we can convince the people that the inebriate belongs exclusively to us we will soon have plenty of practice and money too. The inebriate has paid the legal profession and courts good wages all the time, and if we can turn this great source of wealth into its proper channel it will be a blessing to the profession. Start a petition to Congress, and have all physicians sign it. We have been imposed upon long enough and will fight for our rights.

Hurriedly submitted by

$$
\text { W. P. Howle, M.D. }
$$

\section{A Multiplex Stethoscope.}

Philadelpiria, Feb. 17, 1895.

To the Editor:-The interesting communication of Dr. A. M. Corwin, in the Journal for Feb. 16, 1895, upon a double binaural stethoscope prompts me to send you the accompanying cut of a multiplex binaural stethoscope, which I have been using with much satisfaction to the class and myself, at the Jefferson Medical College Hospital for some

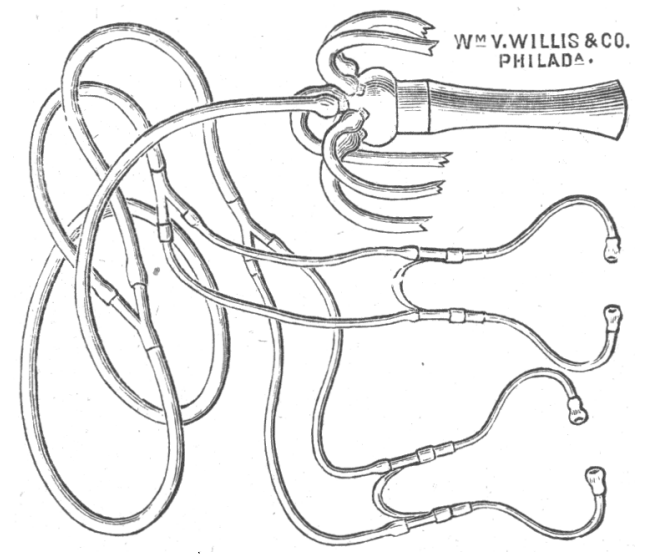

months. By means of this instrument, which was made at my request by $\mathrm{Mr}$. William Willis, a well-known instrument maker of Philadelphia, sixteen students can listen to the heart sounds or any other physical signs demonstrable by auscultation, if these sounds are not so indistinct as to be heard with difficulty even when using a single instrument. With large classes the difficulty is that only two or three men can listen to the heart sounds, while the description of the case is fresh in their memories, but with this multiplex instrument a large number can listen at once with little inconvenience to the patient. If two instruments are employed, thirtytwo men can hear the sounds without interfering with one another; the chest pieces taking up but little room and the tubes being made long enough to extend a considerable distance from the patient. These instruments work satisfactorily in direct proportion to the quality of the materials used in their construction and the care exercised in making: the wooden chest piece. Very truly yours,

$$
\text { H. A. HARE, M.D. }
$$

\section{Lister's Method.}

Minwaukee, Wis., Feb. 14, 1895.

To the Editor:-Will you kindly inform me what Lister's method of chromicizing catgut is and oblige
Yours, etc.,
D. T. SHIMONEK, M.D

307 Grand Avenue.

ANSwER: Lucas-Championierre, in his work on the "Radical Cure of Hernia," thus gives the original formula of Lister, which Lucas-Championierre still adhered to in 1892 :

Olive oil . . . . . . . . . . . . 100

Acid carbolici cryst. . . . . . . . . . . . 20

M.

Water. . . .

Catgut should be immersed in this emulsion not less than six months. Before using the catgut it is soaked for a quarter of an hour in a carbolic acid solution 20 to 100

\section{Correction-Diagnosis of Ieprosy.}

Phinanelpita, Feb. 25, 1895.

To the Editor:-I beg you will correct two typographical errors in my letter, published in the Journal of February 23, concerning "Leprosy and its Diagnosis." The words "and the analgia" should read erythromelalgia, and "ainhumides" should read ainhumoides. The first error as it stands now, makes the reading incomprehensible and senseless. Respectfully, Li)uis A. Duhring, M.D.

Moral: Write so that it can be read. Had our esteemed correspondent written the original as plainly as he has written this one, he would have had no cause for complaint.-ED.

\section{ASSOCIATION NEWS.}

\section{American Medical Association.}

( Office of the Permanent Secretary. 1400 Pine Street, Phir.adelphia.

The forty-sixth annual session will be held in Baltimore, Md.. on 'Tuesday, Wednesday, Thursday, and Eriday, June $7,8,9,9$, and 10 , commencing on Tuesday, at $10 \mathrm{~A} . \mathrm{M}$.

"The delegates shall receive their appointment from permanently organized State medical societies, and such county and district medical societies as are recognized by representation in their respective State societies, and from the medical department of the Army and Navy, and the Marine-Hospital Service of the United States.

"Each State, county, and district medical society entitled to representation shall have the privilege of sending to the dssociation one delegate for every ten of its regular resident members, and one for every additional fraction of more that half that number: Provided, however, that the number of delegates for any particular State, Territory. county, city, or town shall not exceed the ratio of one in ten of the resident physicians who may have signed the Code of Ethics of the Association."

Members by Application.-Members by application shall consist of such members of the State, county, and district medical societies entitled to representation in this AssocraTron as shall make application in writing to the Treasurer, and accompany said application with a certificate of good standing, signed by the president and secretary of the society of which they are members, and the amount of the annual subscription fee, $\$ 5$. They shall have their names upon the 